\title{
The Da'wah Communication Strategy of Jamaah Tabligh in Sub-district of Tondo, Palu City
}

\author{
Nuraedah $^{1 *} \&$ Mutawakkil $^{2}$ \\ ${ }^{12}$ Universitas Tadulako Palu, Indonesia \\ * email.nuraedab_74@untad.ac.id
}

\begin{abstract}
This study aims to analyze the da'wah communication strategy of Jamaah Tabligh that includes planning, implementing and identifying agents of change in the Jamaah da'wah in sub-district of Tondo, Palu. The research used phenomenological method with interviews and observations as data collection techniques. The results showed that Jamaah Tabligh da'wah communication strategies include; first, planning with tafakud which means ensuring readiness. Second, the implementation of da'wah through khuruj emphasizes the practice of Intiqoli (Amal Intiqoli) and the practice of maqami (Amal maqami). Third, the agents of change in the da'wah communication process are individuals and groups. The Agents referred to are abbab karkun and amir. The role of the changer is to change morals to be praiseworthy according to the guidance of the Prophet Mubammad SAW.
\end{abstract}

Keywords: Communication strategy; da'wah; Jamaah Tabligh.

\begin{abstract}
ABSTRAK
Penelitian ini bertujuan menganalisis strategi komunikasi dakwah yang mencakup perencanaan, pelaksanaan dan mengidentifikasi agen perubahan dakwah Jamaah Tabligh di Tondo, Kota Palu. Metode penelitian yang digunakan adalah metode fenomenologi dengan wawancara dan observasi sebagai teknik pengumpulan data. Hasil penelitian menunjukkan bahwa strategi komunikasi dakwah Jamaah Tabligh meliputi; pertama perencanaan dengan tafakud yaitu memastikan kesiapan. Kedua pelaksanaan dakwah melalui khuruj, dengan memperhatikan amalan Intiqoli dan amalan maqami. Ketiga, agen pengubah dalam proses komunikasi dakwah Jamaah Tabligh yakni individu dan kelompok. Agen pengubah yang dimaksud adalah abbab karkun dan amir. Peran pengubah ialah merubah akhlak menjadi terpuji sesuai tuntunan Rasulullah SAW.
\end{abstract}

Kata kunci : Strategi komunikasi; dakwah; Jamaah Tabligh. 


\section{INTRODUCTION}

In sociological studies, religion has multifunctional roles. There are at least three functions of religion which includes maintaining public order, integrative function, and strengthening values (Rojiati, 2019). With these functions, it is understandable that religion has always been a subject of discussion throughout history. One of the interesting studies related to religion is the da'wah movement of Jamaah Tabligh. According to (Budimansyah, 2012), "Among Muslims who carry out a da'wah movement institutionally or organizationally is the Islamic Jamaah (Islam Jamaah) and Jamaah Tabligh.

Da'wah invites people to obey Allah and His Messenger, as it was exemplified in the period of the prophet companions (sahabat). In da'wah, the ruler does not need to step down from power. Da'wah efforts do not require a power or even remove the ruler from his throne. Da'wah only wants the ruler (king) to participate in promoting da'wah into the kingdom. A farmer, trader, student or officers, male or female, young or old, all can do da'wah (Shahab, 2009:16). Da'wah activities comprise transmission and transformation of Islam's message arranged with a good plan, measurable target, and clear direction (Rustandi, 2020: 303).

Historically, for decades, the history of da'wah shows the importance of carrying the practice in facing the varied dynamic of the da'wah object. Furthermore, in modern times, da'wah is not only increasingly important, but also requires strategy, a communication strategy that meet with current situations. The communication strategy allows a communication action to be carried out to reach the targets that have been designed as targets of change (Herman, 2017).

Da'wah is obligatory for all Muslim. There is no reason for a muslim to not doing da'wah unless one has died. The meaning of da'wah is wider than just delivering speech. Da'wah can be varied in accordance with each individual muslim ability. Qur'an mentions the obligation of da'wah for muslims in some verses. First, surah Fushsilat: 33 (Departemen Agama, 2005:480), which says: "Who is better in his religion than those who invite people to (religion of) Allah and doing good deeds and saying 'I am part of Muslims (those who surrender to Allah)". Second, Qur'an Surah Adz Dzaariyaat, [55] (Departemen Agama, 2005:523): "And keep giving warnings, because indeed the warnings are beneficial for the believers." Third, the Qur'an (Thaahaa [132]: 321): "And command your family to do salat and be patient in doing it. We do not ask. for 
sustenance for you, we provide it for you. And the (good) consequence is for the pious". Fourth, Al-Quran (Ali Imran, [110]: 64): "You are the best of people who are expelled for the (benefit) of mankind, you command (do) to good and prevent from evil, and you believe in Allah."

The position of human being as objects of da'wah, by seeing the importance of da'wah, can refer to Al Quranul Karim and the Prophet Muhammad SAW that order it as an obligation (fardu). For Muslims who have ability, meet the requirements from the aspects of Iman (faith), Islam, knowledge, and khuluki, then da'wah for him is Fardu Kifayah with the predicate Da'i. The second predicate is Fardu'Ain which is applied for all Muslim individuals and is called $\mathrm{Ra}^{\prime}$ in, because being $\mathrm{ra}^{\prime}$ in can be implemented by any muslim, anywhere, and anytime. The da'i and Ra'in both are the subjects of da'wah (Kafie, 1993:29-30). The subject of da'wah is important, apart from being a preacher, they also serve as communicator as well as a narrator. This means that the subject of da'wah is a person who has the ability to communicate and convey Islamic messages strategically.

Research that relevant with and supporting this research can be seen in some writings related to communication strategies. For example, (Sudarman, 2018) in his research concluded that the communication strategy carried out included planning, media selection, implementation, and evaluation. Furthermore, in his research on Hidayatullah da'wah communication strategy, (Arifin, 2018) explained that the stages in the guidance activities carried out by the da'i Hidayatullah are the initial basis for determining the patterns and strategies that can lead community to their ideal goals. The stages include: first, identification of the problem; second, the existence of an agent of change; third, media or channels; and fourth, role of the changer.

Some relevant studies to the study of da'wah strategy of the Jamaah Tabligh includes the writing of Furqan (2015) regarding the role of the Jamaah Tabligh in the development of da'wah. This study suggests that the Jamaah Tabligh has a paradigm that preaching does not always have to be on the pulpit (mimbar). Among the da'wah methods used is the Bayan method, which is the da'wah activity of the Jamaah Tabligh that emphasizes on delivering messages as well as building friendship (silaturahmi). Another is a study from Subu et al. (2017) which discusses the da'wah strategy of the Jamaah Tabligh in the North Luwu Regency area. The results of this study indicated that the da'wah strategy carried out by Jamaah Tabligh in overcoming social conflicts used following ways. First, Jaulah, which means 
visiting fellow Muslims, in order to reminding each other to remain obedient to Allah SWT. The second is Bayan, which means the da'wah strategy with tabligh or lecture activities. The third is Tasykil, which means inviting the conflict actors by encouraging them to spend time in the way of Allah and synergize with the government in creating conducive environment. Further research was conducted by Asror (2018) which discusses the da'wah strategy of the Jamaah Tabligh movement in Pancor City. In his research, he explained that the preaching of Jamaah Tabligh was growing rapidly and relatively did not causing conflict, even though the city of Pancor was dominated by Nahdlatul Wathan Islamic group.

Based on the explanation above, this research focuses on the da'wah strategy of Jamaah Tabligh which from the aspects of planning, implementation, and existence of the agent of change in the continuation of the da'wah of the Jamaah. The type of research used is qualitative research, using the phenomenological method as it is usually applied in studying issues related to the value system, art, culture, history, and personal experience (Sendjaja, 2011). The research was carried out in the mosques of the sub-district (kelurahan) of Tondo, Palu City, which became the Mahalla or place of activities of the Jamaah Tabligh.

\section{RESULT AND DISCUSSION}

\section{The Existence of Jamaah Tabligh in Tondo Kota Palu}

Some people considered the existence of Jamaah Tablight as something unfamiliar in society. Many are wondered; what is Jamaah Tabligh? Some answered that they do not know, some answered they do know yet actually they do not. Some answered that they know it a bit. There are also those who are completely unable to explain, because of their limitations, even though they know. There are those who are able to answer correctly because they really know it.

Until now, no one knows where does the naming of the Jamaah Tabligh came from. People will not find an identification board in front of the mosque in which they work. It is different from other organization or group such as Ahmadiyah and LDII which has secretariat, or Hizbut Tahrir who publishes an iconic magazine or bulletin or Khilafah magazine of Jamaah Khilafatul Muslim and Salafi magazine of salafi studies (including as-sunnah, arrisalah, etc.). There are no letterheads bearing the "Tabligh" symbol, there is also no t-shirts, banners, leaflets, or radios that represent the group, as they normally have by a party (Fahim, 2009:3). 
Abu Muhammad Fahim added that one of Jamaah Tabligh's scholars (ulama), Syech Maulana Tariq Jameel, in his lecture said: "Don't say that we are the people of Jamaah Tabligh because these words divide Muslims". Maulana Saad Kandahlawi also informed that "Tabligh is not the name of a Jamaah but Tabligh is an act that must be carried out by all Muslims" (Fahim, 2009: 4-5).

In less than two decades, Jamaah Tabligh has succeeded in its movement spreading to South Asia. Led by Maulana Yusuf son, Maulana Ilyas, as the second Amir, this movement began to develop its activities in 1946. Within 20 years, its spread had reached Southwest Asia, and Southeast Asia, Africa, Europe and North America. Once formed in a country, Jamaah Tabligh will start to mingle with local.

Jamaah Tabligh entered Indonesia in 1952. From 1974 onwards, their movement began to appear intensively with its preaching center at the Kebun Jeruk Mosque, West Jakarta. Until now, the activities at the mosque are still active, and the place has become the center of coordination for the da'wah activities of all its members who are spread across various regions in Indonesia (Aziz, 2004:468-515).

Yusron Razak (2008) in his dissertation stated that "Jamaah Tabligh is a transnational movement whose direction is not linear, directly touching countries with large Muslim populations. Jamaah Tabligh became a traditionalist religious movement which spread in Southeast Asia in 1952, starting from Malaysia, Singapore and then entering Indonesia, specifically in Medan. This can be seen from the inscription on the Al-Hidayah Mosque, the mosque of the Jamaah Tabligh community in Medan." With the formation of group of Jamaah Tabligh members (rombongan jamaab), its spread has reached to every region in Indonesia including Palu.

Supuani (2004: 29) explained that the existence of the Jamaah Tabligh in Palu City started by the initiative of joined Jamaah from Singapore, Malaysia, and Indonesia in the 1980s. The jamaah anchored at Pantoloan Wani port, until it entered the city of Palu. The first figure who took part in the activities of the Jamaah Tabligh in Palu was Abdurahim. The activities were located at the Palu jami mosque located at Wahid Hasyim street. Furthermore, the activities of Jamah Tabligh began to develop, until finally they have their own base camp at the Awwabin Mosque which is located at Mangga Street.

Supuani's notes proved that in less than ten years the spread of the Jamaah Tabligh movement has succefully managed to enter Central 
Sulawesi. This is because the movement uses the Khuruj fii sabilillah method in the form of a group to come out for preaching in each area.

In general, Jamaah Tabligh da'wah activities in all regions are almost the same, due to regulations and intensive meeting they hold. For example, a biennial international meeting attended by representations from each country. National meetings are held every four months, and every two months at the provincial level. As for the district level, the meeting is held once a month. The meeting discusses reports of da'wah activities in each of the representative areas (Amin, 2012).

The place for meeting or activity center of Jamaah Tabligh is called Markaz. Markaz tabligh is a mosque that is used as a center for activities of tabligh. There is only one markaz Tabligh in one area. For example, the markaz of the Indonesian Tabligh is in The Big mosque (Masjid Raya) of Kebon Jeruk, Jakarta. The Markaz Tabligh in Central Sulawesi is at the Awwabin Mosque, Mangga street. In the provincial markaz, Jamaah Tabligh has a protocol section called istiqbal, which functions to take care of guests outside the region who are performing khurujj or people who are interested in participating in activities held at Markaz. In addition, there is also a tasykil, which functions to monitor the development of da'wah groups in Halaqah and Mohalla, to manage the distribution of the target areas for da'wah. There is also khidmat, which functions in the preparation of logistics, both at Markaz and during khuruj. Then there is the $i^{\prime}$ lan, which is the the information section and there is also a wala pulpit which functions to guide events in the deliberation and discussions (Razak, 2008: 140-141). The change of each section is determined in the meeting and makes the mosque a place for all activities of Jamaah Tabligh.

According to its location, the da'wah activities of Jamaah Tabligh are divided into two form, namely intiqoli and maqomi. Intiqoli is doing da'wah in other people's places or kampong or other areas by moving or by traveling (jaulah or Khuruj fi sabilillab) for a certain period. The visited people or place is expected to give a positive response, so that there is cooperation between the guest and local people, as was the cooperation between the Muhajirin and Anshor in Medina at the time of the Prophet Muhammad SAW. Meanwhile, maqomi is da'wah in each of the Jamaah Tabligh members' places. All worker is encouraged to spend several hours each day in touch with people around their respective places to preach religion. When they preach, there are two related terms of practice (amal): Infiradi and Ijtima'i. Infiradi is practice individually while $\ddot{j t i m a} a^{\prime} i$ is practice in groups 
(berjamaah). Likewise, in da'wah it can also be done through infiradi or ijtima'i (Amin, 2012: 42).

In carrying out its da'wah activities in Tondo, Palu City, Jamaah Tabligh is known by several names. From the results of the analysis it can be explained that the naming of the Jamaah Tabligh is only a matter of labeling. The named group does not identify itself as Jamaah Tabligh. The name is given by community. If we look closely, there are other names can be found in the community. There are those who call it Jamaah Tabligh, Jamaah Jaulah, Jamaah Jenggot (Beard Jamaat), Jamaah Kompor (Stove) and so on. However, the Jamaah Tabligh leaders consider it only a matter of naming. The informant further stated that the reason the community calls it as Jamaah Tabligh is because Jamaah means many or groups while tabligh means to convey. Indeed, the work of this group is to conduct da'wah or deliver religious matters in groups so that it is called Jamaah Tabligh.

Based on the explanation above, the conclusion is that Jamaah Tabligh is a da'wah movement, where their movement is in the form of preaching (tabligh) and da'wah to convey religious teachings to every mankind in a group, known as Khuruj Fii Sabilillah. Based on observation, it can be explained that the activities of the Jamaah Tabligh in Palu are centered at the markaz of the Awwabin mosque on Mangga street. In addition, the jamaah can be identified by several distinctive characteristics. The most dominant characteristics of the Jamaah Tabligh includes practicing good deeds that are seen as part of the Sunnah of the Prophet Muhammad SAW, such as wearing a robe, wearing a turban or wearing a cap, using siwak, wearing loose pants (celana cingkrang), and eating together. In addition, what is most visible to them is $i^{\prime} t$ tikaf (stay for a period of time) in the mosque and visit people's homes to invite them to prosper the mosque. It was also explained that the location of Jamaah Tabligh da'wah was not limited to Tondo. It is just that the Tondo area was seen as a potential area, even though the Jamaah initially received rejection, but gradually with their patience to preach, eventually Perdos residents living in Tondo sub-district was accepted the presence of the Jamaah Tabligh.

\section{Planning Strategy of the Jamaah Tabligh Da'wah}

The da'wah process of Jamaah Tabligh in Tondo, which start from rejection, acceptance, and development cannot be separated from the concrete steps of Jamaah Tabligh workers to continuously doing the 
process. In this sense, the Jamaah Tabligh has certain strategies, starting from formulating the goals to executing the plan. As explained by Effendy (Sudarman, 2019: 44), strategy is basically planning and management in achieving a goal. However, strategy is not like a compass which only shows the cardinal directions, but it must be able to be presented in an operational picture.

In other words, it can be concluded that the da'wah strategy is a comprehensive approach related to how da'wah activities can be carried out, from planning to executing activities within a predetermined period of time. Among the important things in the da'wah strategy of Jamaah Tabligh in Tondo are preparation, implementation, and important actors in the implementation of the da'wah.

Achieving the objectives of da'wah effectively cannot be separated from a careful and measured planning process, starting from identifying problems and challenges, to the solutions to be used. Furthermore, Kayyo, (2007) explains that planning must answer at least six things; starting from what form of da'wah activities? What are the goals that will be achieved from the da'wah process? Where will the da'wah activities be carried out? When will the da'wah be carried out? Who will be involved? What technique will be used?

In the strategic planning of Jamah Tabligh's da'wah, there are several important points. Among others is determining the time and duration of the da'wah activities. In relation to the initial process of da'wah planning, that is when a group of members are going to carry out da'wah or khuruj activities for a long period of time, planning begins with deliberation at the markaz. The deliberation is to determine when, who, and until when a khuruj da'wah is carried out. In addition, deliberation in each family are also carried out, to ensure the readiness of the family who will be left behind.

Before going for khuruj, the Jamaah Tabligh workers must first pay attention to tafakud (readiness) in accordance with the duration of khuruj that will be spent, starting from 40 days, four months or one year. There are at least four things that must be prepared in advance. First, tafakud amal, which means preparing spiritual deeds to leave for khuruj; for example, istiqomah, pray five times in the mosque, sunnah prayers, read the Quran, dzikir and other acts of worship. This preparation aims to build the personal spirituality of each individual Jamaah Tabligh, before calling on others for being religious. Thus, tafakud amal is a process of internalizing spiritual values before transmitting them to others. Tafakud amal refers to 
The Da'wah Strategy of Jamaah Tabligh in Sub-district of Tondo, Palu City

Q.S Al Baqarah verse 44; "Why do you tell other people (to do) worship services, while you are forgetting (your obligations) yourself, even though you read Al Kitab (Taurat)? Then don't you think? " (Ar-Rahim, 2012:7).

Second, the family tafakud (tafakud keluarga), which asks for the readiness of the family to be left behind including the condition of the family and whether or not they are ready to be left. In addition, in the family tafakud process the Jamaah provides guidance, especially for women are encouraged to participate in the masturat, which means closed or veiled. In this guiding process, women are trained to be independent so that when she is left by her husband for the khuruj, she is ready and expected to be able to act as the head of family at home. The training or guiding process was inspired by Q.S at-Taubah verse 24 which means; "Say: 'If fathers, children, brothers and sisters, your wives, your family, the wealth that you are working on, the commerce that you are concerned about the losses, and the place to live that you like, are to be loved more than Allah and than jihad in God's way, just wait until Allah brings His decision ". and Allah does not guide the fasik" (Ar-Rahim, 2012:190).

Third, work tafakud (tafakud pekerjaan), which means that when a Jamaah Tabligh member is leaving for khuruj, they need ensure that it is not disturbing their work. For example, for an office employee, one must get the permit or take time off. It also includes the muamalab issues (such as personal debt) and muasyarah (relationship with relatives must be established).

Fourth, tafakud amwal (costs), meaning the readiness of saving (an amount of money) for the family and the readiness of costs to be carried out for khuruj. Khawiyu (2019:10) added that tafaqud amwal includes activities to prepare a certain amount of money to be used in carrying out da'wah as well as money to given to the wife to fulfill her needs during her husband khuruj.

The preparation and planning above is an individual plan, which is generally carried out by all Jamaah Tabligh members. Meanwhile, the preparation and planning of dak'wah of Jamaah Tabligh in Tondo subdistrict, started with the guidance and direction from the Jamaah at the Palu markaz, precisely on Jalan Mangga, to conduct da'wah in the Tondo urban village for three days. Then they invited the other Tondo people to go out for three days. So that the Tondo people who have been out preaching for three days will do the same thing as the process they did at the beginning. They then invited the people of Tondo who had the same vision and 
mission to join in the da'wah. So that there were some residents of Tondo, both academics, office employees, students and the general public to join the activities. Subjects who participated in the initial period of preaching or those who come from student groups.

The organizer of the da'wah strategy in sJamaah Tabligh is called karkun when it has been out for three days or it is called abbab. They set the strategy for preaching or khuruj in Perdos. In its implementation, the planning strategy begins with secret da'wah. Initially, the preaching was started within students communities. This period is a new or early period in the preaching of Jamaah Tabligh in Tondo, it is concluded that the reformers in the Jamaah Tabligh movement in Tondo are students.

\section{The Implementation of Jamaah Tabligh Da'wah}

In the implementation of their da'wah, Jamaah Tabligh emphasizes persuasive approaches by, among others, internalising and then transmitting Islamic values. This approach is used based on an understanding that da'wah is a process of actualisation of islamic teaching. In accordance with the definition of da'wah described by Syamsudin as the actualization or realization of one of the original (kondrati) functions of a Muslim, that is the prophetic (kerisalahan) function in the form of a conditioning process so that someone or the community knows, understands, believes and practices Islam as a teaching and way of life.

Because da'wah is part of the actualization, the da'wah of Jamaah Tabligh also features religious rituals in addition to the da'wah of tabligh or lectures that are usually carried out. Based on practices (amalan), da'wah activities of Jamaah Tabligh include; first, the practice of intiqoli, meaning the practice of da'wah in other people or in other areas by moving or by traveling (Jaulah or Khuruj fi sabilillab) for a certain period. The period used has been determined by taking the time divided into three days, 40 days; there are 40 days of walking, 40 ordinary days, 40 days of distant lands, then four months, there are four months of regular walking, four months of walking and four months to places further away (Supuani, 2004: 53). Khuruj $f i$ sabilillah is spending total time preaching, which is usually from mosque to mosque and led by an Amir (leader).

The process of khuruj consists of various activities including taklim by reading Hadith and the stories of the companions that are sourced from the book Fadhailul Amal by Maulana Zakaria; Jaulah or visiting houses around the mosque to invite the residents to practice Islam 
comprehensively. In addition, khuruj is also consists of bayan mudzakarah which consists of activities to memorising the attributes possessed by the companions of the Prophet. Another activity is karkuzari which means giving a daily report to the travel leader or amir. The last is meeting or deliberations to formulate further agenda as well as evaluate the completed activities during khuruj.

Second, amalan maqami, which means the da'wah activity of the Jamaah Tabligh which focuses on Mohalla (mosque) of the Jamaah member in their respective homes (Shahab, 2009: 319). This activity emphasizes the practice of Maqami in order to make every karkun (people joined the Jamaah Tabligh) to realize the strength and maintain the practice of religion after returning from Khuruj Fisabillah. Ishaq Shahab explained that there are five Maqami practices that must be carried out when karkun returning from Khuruj Fisabilillah which includes deliberation meeting or daily thinking, silaturahmi at least 2.5 hours every day, taklim at mosque and taklim at home, Jaulah I and Jaulah II.

Jamah Tabligh in Tendo, carried maqami practices by prospering the mosques with islamic studies (pengajian) and jaulah. In the process, the practice of maqami is required to produce future cadres. As in the process, the practice of maqami in Tendo has been done in various places of activity, from office mosques to mosques in educational institutions. The first step in creating cadres is done by intensive jaulah and staying for three days in the nearest mosques, followed by organizing taklim, and deliberation with limited karkun. Soon after, after the practice of maqami was done continuously, it finally paid off, with the increase of Jamaah Tabligh sympathizers from academic group. It is can be seen from the participation of some important figures from Tadulako University with the Jamaah Tabligh.

In addition to carrying amalan maqami to prospering the mosque, the regeneration process is being done through gathering activities. Other activities include khuruj as a way to get new khuruj cadres; the recruitment is started with silatuhrahmi, reading, taklim, and deliberation meeting. The development has grown quite fast as the Darul Hikmah and Babul Ulum mosques have composed separate group, without the help of other mosques. Regarding reading taklim, it can be seen from reading the hadith and stories of the prophet companions. These activities are expected to build strong religiosity that can strengthen their spirit and faith.

Another important thing in the implementation of Jamaah Tabligh 
da'wah is Taklim Wata'llum (religious teaching). Taklim Wata'llum is a practice that is considered very important to be done, both in the mosque with congregations and at home with family. Taklim wata'llum in Jamaah Tabligh is divided into two ways, namely taklim fadhail and taklim masai'l. Taklim fadail is a kind of learning forum that studies the advantages (fadhail) in doing good deeds and the disadvantages of leaving them. Taklim fadail is emphasized in each da'wah worker (karkun) by living the practice in the mosque with congregation and in their respective homes with family. Taklim masai'l, meanwhile, is a kind of learning forum that studies the laws of religion by visiting ulama learn from them about the laws of religion.

Jamaah Tabligh worker (Karkun) are also required to practice this taklim masai'l in order to know which ones are ordered by religion and which ones are prohibited, which ones are permitted by religion and which are forbidden. Another activity being done during khuruj for three days is giving religious lectures. According to Mahdi (2007) in every bayan or lecture, the first thing that is often conveyed is the importance of doing da'wah and tabligh. Another effort to encourage the karkun to be active in da'wah activities is to praise the new karkun - especially the young ones with the words "subhanallah wa gratitude" and to embrace and talk intimately about their impressions when doing khuruj. The senior karkun also encourage the new karkun to continue to be istiqomah (consistent) in their da'wah and tabligh, to visit houses around the mosque by inviting residents into the Islam kaffah without coercion, memorizing the nature of prophet companions, and deliberation. During this khuruj period, the karkuns sleep in the mosque.

Other practices include deliberation and jaulah. The development of the Jamaah Tabligh da'wah can be seen when a mosque creates its own group of khuruj. This indicates that the mosque has developed the amal da'wah of Jamaah Tabligh. Sakdiah (2017) stated that deliberation is one of the principles of managing many aspects of collective life in accordance with the Quran, including the life of da'wah. In this sense, all member of the community in their community life is required to always hold deliberation. In 2002, Jamaah Tabligh in Tondo Sub-district had not had an activity center for conducting deliberations which was called the Halaqah Sentral. The center of Halaqah functions as a meeting place for each da'wah worker in one area. The aims and objectives of deliberation in Jamaah Tabligh community is to consolidate the thoughts, suggestions, and methods of work, so that everyone is ready to accept and practice religion 
perfectly. In this way, religion can manifest itself in the oneself, family, society. The ahbab/karkun of Jamaah Tabligh are very obedient to the decisions taken in the deliberations that are decided by the Amir musyawarah (deliberation leader). The form of deliberation they conduct are divided into several forms of daily deliberation, halaqah deliberation, and monthly deliberation.

Jaulah (Silaturahmi) in Jamaah Tabligh is the backbone of da'wah. Jaulah brings patience, tawadhu, sincerity, goodness and other qualities. Jaulah aims to build cooperation between mohalla or mosques to make the practice of maqami applied perfectly. Jaulah is carried out in every mohalla or mosque in Tondo, usually after Maghrib prayer and is held two times a week. The day of activity is determined during monthly deliberation. In order to carry out an effective jaulah program, it is recommended that the program followed by eight or more people. However, directions from the ulama of the Jamaah Tabligh said that, even though in one mohalla or mosque there is only one karkun, jaulah must go on. Jaulah consists of two groups, on group inside the mosque and another outside the mosque.

The implementation of Jamaah Tabligh da'wah features a consolidating concept, meaning that the da'wah being carried out is the da'wah that emphasizes the principles of brotherhood. Da'wah like this takes the function of religion as an instrument of social glue. As has been emphasized by Comte Shonhaji (2012:17) who explained that religion creates consensus which in turn can become the glue between its believers.

\section{Agent of Change of Jamaah Tabligh}

In community, there are always individuals who become references as well as key actor of movement, they are usually called the Agent of Change. They are individuals or groups who are trusted as leaders whose presence is influential in the social life of society (Soekanto, 1992: 273). In Jamaah Tabligh, there are agents of change and key actors for the movement, both individuals and groups. They carry out their duties, including activities of community development and assistance.

Based on the research result, it can be explained that the agent of chance of Jamaah Tabligh in Tondo is located in Moballa which then forms balaqah. Halaqah is a term that has relevance to education, especially da'wah education or the teaching of Islamic values (tarbiyah Islamiyab). The term halaqab (circle) is usually used to describe the activities of a small group of Muslims who regularly study Islamic teachings. Their number of 
participants in the small group ranged from 3-12 people. In the process, the halaqah participants studies Islam with a certain curriculum and method. Usually the material and curriculum comes from community supervisors or leaders (Karim, 2018).

In halaqah there is Amir (leader of Halaqah). Such leadership is very important, without a leader the religious process will not run properly. According to Effendi and Rustandi (2020), the presence of socio-religious groups is driven by the process of emerging leadership. In the community of Jamaah Tabligh, amir take the position of agent. It is because amir is usually the initiator of the halaqah as well as the policy holder for the development of karkun cadres.

Agent in the Jamaah Tabligh community is not only emir individually. In practice, major changes are created in the karkun community. An example is the formation of a new halaqah that occurred in 2012. Initially the Halaqab Tondo had not been formed. The first Halaqah was active at the Istiqlal Mosque on Juanda street, its name was Halaqah Palu Timur, it was in 2002. Along with its development, in 2005, with the increasing number of karkun, the karkun asked for a deliberation and it was in the deliberation at the markaz on Mangga street, it was decided to form a Halaqah separated from the older one with the name Halaqah Tondo, located in Talise, at the Al-Ambar mosque.

In 2012, Jamaah Tabligh in Tondo grew with the increasing number of mosques that carrying religious deeds. The karkun Tondo held a deliberation to form its own Halaqah. After the Palu ijtima was held in Taipa, a kargozari or report that some karkun wanted to separate and make their own Halaqah. In 2012 after approval from the markaz at Mangga street, Tondo made its own Halaqah which was located at the Darul Hikmah Mosque. The purpose of this separation is to ensure that the work of the karkun is better coordinated. In addition, once Moballa's number is sufficient, one halaqah can be made.

Based on the above explanation, the authors conclude that the Halaqab Tondo which was founded in 2012 was initiated from the East Palu Halaqab which is located at the Istiqlal Mosque on Juanda Street. The growing development of Jamaah Tabligh preachers in the West Palu section, especially in Tondo, prompted the birth of a deliberation at the Palu markaz at the Awwabin mosque in 2005 to add new Halaqab namely Talise and Tondo which was located at the Al-Ambar mosque, Talise, a fishing kampong complex. However, the name Halaqah is still called 
The Da'wah Strategy of Jamaah Tabligh in Sub-district of Tondo, Palu City

Halaqab Tondo. The Halaqab Talise was made because for several reasons: every karkun is easily controlled by seeing the increasing number of people taking part in this congregation; also, it also makes it easier for Tondo people to get access to halaqah deliberations.

After going through the ijtima process from the association of Jamaah Tabligh members throughout the city of Palu in 2012 in Taipa, by referring to and seeing the kargozari (report) of Tondo da'wah workers, it was decided that Tondo can have a separate Halaqah. Another consideration is the fact that the mosques in Tondo have carried a lot of religious activities. Based on deliberation, it was also decided to form the center of Halaqab Tondo at the Darul Hikmah Mosque on Untad I road since 2012-2017. Agent of change for this development are abbab or karkun and Amir who leads the halaqah deliberations and during the khuruj.

The next is the role of the changer. The halaqah deliberation is held once a week. The role of the karkun or ahbab is to influence or making positive changes in attitudes and behavior of community. In addition, senior karkun must have the ability to build public trust to recruit new karkun. Once trust is built between the senior karkun and the karkun candidate, a friendship will emerge that in turn will create religious solidarity. In addition, deliberation is carried out based on brotherhood, care, togetherness and acceptance, so that communication strategies through da'wah messages can be conveyed by karkun in the community.

The agent of change, in this case, are the ahbab or karkun and the halaqah group who have played a lot of roles during deliberations and jaulah. The role of ahbab/karkun can be seen from amal intiqoli and maqami which are the appearing practices when they go out for da'wah. This practice is known as the Khuruj Fii Sabilillah. It is one of the important activities that play a role in Jamaah Tabligh group. Khuruj also a way for to get self-improvement (islah). Khuruj is carried out from house to house and from mosque to mosque on foot and is led by an Amir (leader of the Halaqah).

In creating change in community, an agent of change needs to have innovation in terms of da'wah material and this is also one of the important things that need to be considered by the da'wah actors of Jamaah Tabligh. In this context, in their research about Nahdlatul Ulama (NU) and Muhammadiyah, Suherdiana \& Muhaemin (2018) wrote that "the material of da'wah is still centred in the area of faith, morals, and muamalah. Current issues that require study and solutions from an Islamic perspective are still 
relatively limited". Discussing contemporary issues is also seen as important for the karkun and emirs in Jamaah Tabligh when conducting da'wah, both during khuruj or not. By discussing contemporary issues, it is hoped that Jamaah Tabligh preaching will not go partially, which only focuses in spiritual development.

Khuruj can be done at least four months in a lifetime or 40 days every year. During khuruj, the Jamaah Tabligh group often goes out of town, even abroad, to the markaz centre of the Jamaah Tabligh in India-PakistanBangladesh. The Khuruj period is sometimes questioned by the common people, especially in regards to the aspect family considerations, given the fact that the khuruj time that can take 3 days, 40 days, and event 4 months. However, it is a guide that must be done in Jamaah Tabligh.

Furthermore, in khuruj, amir has a controlling role in the activity of the karkun. A number of rules must be followed during khuruj which include: four hours for da'wah, four hours for Taklim, four hours for diciker worship, four hours for Khidmat. The khidmat consists of: Khidmat to the Amir, khidmat to the Jamaah, Khidmat to the resident and khidmat to oneself. In total the total schedule activities is around 16 hours, the remaining 6 hours are used for sleep and 2 hours for other personal needs. If they leaving in an orderly manner by fully following the practice of ijtima'i, then with Allah's permission they will get Ishlah (self-improvement) after returning. You can keep your prayers in jamaah, mu'asyarah and mu'asyarah will be better. In the understanding of the Jamaah Tabligh community, the failure of people to go out in the way of Allah because they do not participate the activity in an orderly manner so that there is no selfimprovement. The result is difficult to be fixed and will become a barrier for other people to obtain guidance (bidayah). One of the main target of Jamaah Tabligh in doing khuruj is self-improvement so that the deeds of worship increase. The biggest target is for all mankind being to practicing religion perfectly and introducing the da'wah to communities members.

The role of changer is to change morals to be praiseworthy, to become religious figures who are morally and religiously intelligent so that the number of cadres of abbab and khuruj will increase. The role of changer in the activities of Jamaah Tabligh is to create human beings who practice religion faithfully according to the guidance of the Prophet Muhammad SAW, to do good deeds, to do da'wah that give benefit to human being on the earth.

The agent of change above have important role in creating a society 
that has moral and spiritual awareness. The role of agent as described by Griffin and Pareek (Juwita, 2019) is as a catalyst for the development of society. Furthermore, both amir and karkun have a role as agents of change who help community or the Jamaah Tabligh itself.

\section{CONCLUSION}

The result of this study showed that the da'wah strategy of Jamaah Tabligh emphasized consolidating da'wah with regeneration of the Jamaah cadres. Furthermore, there are some important aspects of the da'wah of Jamaah Tabligh in Tondo. First, its planning applies a concept of four preparations which include tafakud amal, family tafakud (tafakud keluarga), work tafakud (tafakud pekerjaa) and amwal tafakud. Second, in its implementation, Jamaah Tabligh carries out da'wah through the practice of Intigali and practice of Maqami. Third, in the aspect of agents of change, it can be identified that agents of change in Jamaah Tabligh da'wah consists of emir as an individual or the karkun as a group. In addition, the actions of agents of change that have been carried out include unifying thoughts and method of action so that everyone would accept and willing to practice religion perfectly that manifest in themselves, families, and societies. Beside, the role of the changer is to change morals to be praiseworthy, to become religious figures and morally and religiously intelligent so that the number of cadres of $a b b a b$ and khuruj increase.

In addition, some advices generated from this study are as follow. First, Jamaah Tabligh supports for the awareness of Muslims to always doing good deeds based on the guidance of Rasululah SAW. By using da'wah strategy starting from planning to the importance role of agent of change, it is hoped that the material of the da'wah delivered by the Jamaah is enriched with contemporary issues, so that the da'wah being carried does not seem to be partial. Second, the negative assumption regarding the disharmony of the responsibility of da'wah and family in Jamaah Tabligh movement, comes from the limited knowledge of people about the concept of tafakud. For this reason, this concept needs to be continuously socialized, so that it can minimize the bias of the common people about Jamaah Tabligh.

\section{REFERENCES}

Amin, E. (2012). Dakwah Rahmatan li Al-'Alamin Jamaah Tabligh di Kota 
Jambi. Jurnal Komunikasi Islam, 2.

Ar-Rahim. (2012). Mushab Al-Quran dan Terjemahan. Bandung: Kementrian Agama RI.Mikraj Khazanah Ilmu.

Arifin, B. (2018). Strategi Komunikasi Dakwah Da’i Hidayatullah dalam

Membina Masyarakat Pedesaan, Communicatus: Jurnal Ilmu Komunikasi, 2(2), 159-178. DOI: DOI :10.15575/cjik.v2i2.4940.

Asror, M. Z. (2018). Strategi Dakwah Gerakan Jamaah Tabligh di Kota Pancor, SOSIO EDUKASI Jurnal Studi Masyarakat Dan Pendidikan, 2(1), 39-45. DOI: $10.29408 /$ se.v2i1.1194.

Aziz, M. A. (2004). Imu Dakwah. Jakarta Timur: Prenada Media.

Budimansyah, B. (2012). Gerakan Islam Jama'ah Tabligh dalam Tinjauan Maqâshid Al-Dîn, Al-'Adalah, 10(1), 255-265. https://media.neliti.com/media/publications/57416-ID-gerakanislam-jamaah-tabligh-dalam-tinja.pdf.

Departemen Agama, R. I. (2005). Al-Qur'an dan terjemahan. Jakarta: PT Syaamil Cipta Media.

Effendi, D. I. (2020). The Identity Construction of Da'wah Leadership on Jama'ah Tabligh Movement, Ilmu Dakwah: Academic Journal for Homiletic Studies, 14(1), 133-150. DOI :10.15575/idajhs.v14i1.9210.

Fahim, A. (2009). Inilab Kedok Jamaah Tabligh. Cetakan ke-11. Ttp:Yasa Ishaq, A, N. (2009). Khuruj Fisabilillah. Bandung: Al Ishlah.

Furqan, F. (2015). Peran Jama'ah Tabligh dalam Pengembangan Dakwah, Jurnal Al-Bayan: Media Kajian Dan Pengembangan Ilmu Dakwah, 21(2), 114. DOI: http://dx.doi.org/10.22373/albayan.v21i32.419.

Herman, H. (2017). Strategi Komunikasi Pengelolaan Zakat, Infak, dan Sedekah (ZIS) Melalui Media Sosial, Communicatus: Jurnal Ilmu Komunikasi, 1(2), 171-190. DOI :10.15575/cjik.v1i2.4833.

Juwita, R. (2019). Artikel Konsep Dan Peranan Agen Perubahan.

Kafie, J. (1993). Psikologi Dakwah. Surabaya: Offset Indah.

Karim, H. A. (2018). Urgensi Halaqah dalam Akselerasi Dakwah, At-tahriq: Jurnal Dakwah dan Komunikasi, 2(2), 315-335. https://ejournal.metrouniv.ac.id/index.php/ath_thariq

Kayyo, R. B. (2007). Khatib Pablawan, Manajemen Dakwah; Dari Dakwah Konvensional Menuju Dakwah Profesional. Jakarta: Amzah.

Khawiyu, A. (2019). Pemberian Nafkah Terhadap Keluarga (Studi Kasus Aktifitas Khuruj Jama'ah Tabligh Di Kota Kendari), Jurnal Syariah Hukum Islam, 2(1), 1-15. http://journal.iaialmawar.ac.id/index.php/JSHI/article/view/177 
Mahdi, H. (2007). Interaksi Sosial Jamaah Tabligh di Kota Malang (Studi tentang Interaksi Sosial Jamaah Tabligh di Masjid Pelma dan Ponpes Jami'urrahman Malang), El-Qudwah., http:// ejournal.uinmalang.ac.id/index.php/lemlit/article/view/205 4/pdf.

Razak, Y. (2008). Jamaah Tabligh: Ajaran dan Dakwahnya. Disertasi Sekolah Pascasarjana Universitas Islam Negeri (UIN) Syarif Hidayatullah.

Rojiati, U. (2019). Manajemen Komunikasi Sosial Penganut Agama Baha’i. Communicatus: Jurnal Ilmu Komunikasi, 3(1), 1-16. DOI: 10.15575/cjik.v3i1.5033.

Rustandi, R. (2020). Dakwah Komunitas di Pedesaan dalam Perspektif Psikologi Komunikasi, Irsyad: Jurnal Bimbingan, Penyuluban, Konseling, dan Psikoterapi Islam, 8(3), 301-322. DOI: 10.15575/irsyad.v8i3.2009.

Sakdiah, S. (2017). Masthurah dalam Dakwah Jamaah Tabligh (Analisis Metode dan Praktik), Al-Idarah: Jurnal Manajemen Dan Administrasi Islam, 1(1), 67-86. https://jurnal.arraniry.ac.id/index.php/alidarah/article/view/1540.

Sendjaja, S. D. (2011). Komunikasi: Signifikansi, Konsep, dan Sejarah. Modul Pengantar Ilmu Komunikasi: Universitas Gunadarma.

Shahab, A. N. I. (2009). Khuruj fi Sabilillah. Bandung: Pustaka Al-Ishlah.

Shonhaji, S. (2012). Agama Sebagai Perekat Social Pada Masyarakat Multikultural, Al-Adyan: Jurnal Studi Lintas Agama, 7(2), 1-19. http://ejournal.radenintan.ac.id/index.php/alAdyan/article/view/5 02.

Soekanto, S. (1992). Sosiologi Suatu Pengantar. Jakarta: PT Raja Grafindo Persada.

Subu, A., Arifuddin, A., \& Jasad, U. (2017). Strategi Dakwah Jamaah Tablig dalam Realitas Konflik Sosial di Kecamatan Masamba Kabupaten Luwu Utara, Jurnal Diskursus Islam, 5(1), 30-42. http://journal.uinalauddin.ac.id/index.php/diskursus_islam/article/view/9637/6740.

Sudarman, A. (2018). Strategi Komunikasi untuk Meningkatkan Kesadaran Masyarakat dalam Membayar Zakat Maal, Communicatus: Jurnal Ilmu Komunikasi, 2(1), 39-58. DOI: https://doi.org/10.15575/cjik.v2i1.5056.

Suherdiana, D., \& Muhaemin, E. (2018). The Da'wah of Nahdlatul Ulama and Muhammadiyah in Social Media of Facebook, Ilmu Dakwah: Academic Journal for Homiletic Studies, 12(2), 187-200. DOI: ttps://doi.org/10.15575/idajhs.v12i2.6176. 
Nuraedah \& Mutawakkil

Supuani. (2004). Jamaah Tabligh di Palu. Pendidikan Sejarah. Palu: Jurusan Ilmu Pengetahuan Sosial. FKIP UNTAD. 